\title{
FAVOURITE RESEARCH TOPICS OF ESTONIAN ETHNOGRAPHERS UNDER SOVIET RULE
}

\author{
INDREK JÄÄTS \\ Researcher, PhD \\ Estonian National Museum \\ Muuseumi tee 2, 60532 Tartu, Estonia \\ e-mail: indrek@erm.ee
}

\begin{abstract}
Estonian ethnography as one of the Estonia-related disciplines was tied with Estonian nationalism from the very beginning. Defined as a science investigating mainly the material side of vanishing traditional peasant culture in the 1920s, it fitted rather well with the Soviet understanding of ethnography as a sub discipline of history. Thanks to the major cooperation projects initiated and coordinated by ethnographers from Moscow, Soviet Estonian ethnographers could continue studying Estonian traditional peasant culture. Their favourite research topics (folk costume, peasant architecture and traditional agriculture) supported Estonian national identity, but also suited the framework of Soviet ethnography. Studying contemporary (socialist) everyday life was unpopular among Estonian ethnographers because the results had to justify and support Soviet policy. They did so unwillingly, and avoided it completely if possible. Despite of some interruption during the Stalin era, ethnography managed to survive as a science of the nation in Soviet Estonia.
\end{abstract}

KEYWORDS: history of ethnology • nationalism • Estonia • Soviet Union

\section{IN TRODUCTION}

This article is dedicated to the research topics pursued by Estonian ethnographers under Soviet rule (1944-1991). Which topics did they prefer, and which did they try to avoid and why? Estonian ethnography, ${ }^{1}$ intimately tied with Estonian nationalism from its beginnings in the late 19th century, was subjugated to Soviet ideology and incorporated into Soviet ethnography after the Second World War. Focusing on three favourite research topics of the Soviet Estonian ethnographers (folk costume, peasant architecture and traditional agriculture), I show their connection with both Estonian national identity and Soviet ethnography and come to the conclusion that there was more continuity than change in Soviet Estonian ethnography. I claim that ethnography as an Estonia-related discipline remained connected to Estonian nationalism even during the Soviet period, especially from the late 1950s, and did support Estonian identity. 
The history of Estonian ethnography during the Soviet period has remained a little studied subject. The overviews published in Soviet Estonia (see for example Peterson 1966; Viires 1970a) had to follow guidelines and rhetoric laid down by the ruling communist ideology and lacked the necessary temporal distance. (One well-informed view from abroad was published in the USA [Ränk 1978].)

Estonian ethnography has become part of European ethnology since the restoration of Estonian independence in the early 1990s. The name of the discipline was changed accordingly and its history was rewritten to reflect the paradigm shifts (see Viires 1991; Vunder 1996; Viires and Tedre 1998; Leete et al. 2008; Annist and Kaaristo 2013). Since re-independence only a couple of overviews dedicated especially to the Soviet era have been published (Viires 1993; Johansen 1996), along with articles devoted to specific subtopics (see for example Luts 1999; Konksi 2004; 2009; Astel 2009; Niglas and Toulouze 2010).

Researchers are well aware of the nationalistic essence of Estonian ethnography in the late 19th and early 20th centuries, but have neither analysed nor stressed the continuation of this link to the Soviet period. Ants Viires, author of the most thorough and detailed, yet somewhat descriptive, ${ }^{2}$ overview of Soviet Estonian ethnography (1993), and also the main author of disciplinary histories in collective volumes on Estonian folk culture (Viires and Tedre 1998; Leete et al. 2008), was himself the most prominent and fruitful Estonian ethnographer. He was an active participant in the process under investigation, probably making it a bit difficult for him to see it from outside. His professional education came partly before the Second World War and centred mainly on traditional peasant culture. The connection between Estonian ethnography and nationalism was probably so self-evident for him that he did not even think about it. On the other hand I started my academic career in the late 1990s, studied ethnic processes, nationalism and nationalities policy for a year, and believe that this helps me to see the connections between nationalism and ethnography in Soviet Estonia. In addition to existing literature on the history of the discipline and academic and non-academic texts published in the Soviet era, I rely on interviews with former colleagues made by Karin Konksi in 2004, and by myself in 2018-2019.

Of course, research topics are not the whole picture of Soviet Estonian ethnography, although they are an important part of it. I hope that my somewhat sketchy paper is a step towards more exhaustive analysis of our discipline under Soviet rule.

I begin with a brief overview of earlier traditions of the Estonian ethnography, then proceed to the ideological and institutional frames of the Soviet period and focus finally on the research topics Estonian that ethnographers either preferred or avoided.

\section{ESTONIAN ETHNOGRAPHY AS A SCIENCE OF THE NATION}

Up to the late 19th century, Estonians were a peasant people without an ethnic elite of their own. Estonians were what might be called an ethnographic object of interest for some Baltic German and Russian scholars. ${ }^{3}$ Their Finnish colleagues on the other hand saw Estonians as a kindred people, linguistically quite close to the Finns. Finnish ethnography developed somewhat earlier than its Estonian counterpart and deeply informed it. (Viires and Tedre 1998: 17) 
In the late 19th century, the first Estonian intellectuals emerged, devoting attention to the intangible sides of peasant culture - folk songs (runo songs), legends and folk tales. These began to be collected and published. This happened in a different context to the past, i.e. it was now part of a national movement. Estonians as peasant people or a non-dominant ethnic group (Hroch 2000) lacked their own written history (glorious kings, tradition of statehood) and the intellectuals who started constructing the modern Estonian nation had little to rely on besides traditional peasant culture, which was ascribed a new meaning and as such became (and has remained) important from the standpoint of national identity.

Interest in old folk songs led some contemporaries to devote attention to the material side of peasant culture as well. Estonian ethnography can be seen as stemming from folkloristics, and initially the two were closely intertwined. Both were important tools of Estonian nation-building. It was believed that people's individuality (the main justification for its existence and future survival) took shape through history and was best expressed in traditional folk culture (see for example Manninen 1924: 527, 537).

Estonia was changing quite rapidly in the course of modernisation in the late 19th and early 20th centuries. Traditional folk culture was giving way to various novelties. Folklorists and ethnographers interested in old peasant culture realised that if they wanted to study and preserve it for the future generations, they had to act quickly. The concept of ethnography as "a national rescue action" (see Löfgren 1990: 4) proved to be a long-lasting one.

The Estonian National Museum (ENM) was established in 1909 in Tartu first as a repository of folklore collections, focusing initially on the material side of older peasant culture, above all on collecting and popularising of folk art (Leete et al. 2008: 16-17). Although lacking a fixed address, the museum played an active role in the first decade of its existence in the Estonian national movement. Under the auspices of the museum, a number of expeditions took place, increasing the museum's collections as well as Estonian self-awareness and appreciation of their peasant cultural heritage. Over the years, the museum amassed large collections of artefacts and by the World War One years, a need to systematise and study the collections had arisen.

The Republic of Estonia, proclaimed in 1918, was a young nation-state that had to build its own education and research system from the ground up. Along with other Estonia-related branches of knowledge (folkloristics, history, archaeology, linguistics, history of art and literature), ethnography gained the opportunity to become an independent academic discipline that was to make a contribution to strengthening national identity.

There were not enough Estonians with the requisite training in these fields and scholars from abroad (mainly Finland and Sweden) were invited to develop Estonian higher learning. A young Finnish researcher, Ilmari Manninen (1894-1935), came to teach ethnography at the University of Tartu and also became the director of the ENM, the main institutional base for ethnographers.

Manninen laid the foundation for Estonian ethnography as an academic discipline. By defining ethnography as a branch of scholarship that investigated the material side of peasant culture, Manninen reinforced the ties between the discipline and the museum's ethnographic collections. He stated that the goal of ethnographers was to create an integral view of material peasant culture. To do so, they first had to develop a typol- 
ogy of cultural phenomena and determine the geographic range of these phenomena. In addition, the associations between the cultures of Estonia and its neighbours had to be determined. Manninen also emphasised the need to study the historical context of ethnographic objects and the environment in which they were manufactured and used. (Manninen 1924)

Manninen implemented the historical-geographical approach in Estonian ethnography, which was also followed elsewhere in Central and Northern Europe. Mapping became an important method in this connection, mainly when processing museum collections, but also in research. Estonian ethnographers became European leaders in terms of the successful implementation of the cartographic method. (Viires 1970a: 233234; Talve 1992)

The main research topics for Estonian ethnographers were folk costume, buildings, fishing, apiculture and food. ${ }^{4}$ The ENM was the main (re)presenter and (re)constructer of folk culture. Its permanent exhibitions on Estonian cultural history (opened in 1927) became a national manifestation. Estonian folk culture was presented in a somewhat idealised fashion as separate, unique and static. (Metslaid 2016: 62)

The ties between ethnographers, the ENM and state power became even deeper after Estonia took a turn toward authoritarianism in 1934. Ethnographers were expected to join in actions to promote national culture, especially the popularisation of folk costume, firstly in the context of song festivals. ${ }^{5}$

In general, Estonian ethnographers of the 1920s and 1930s took part in the nationalist discourse with the (subconscious) goal of contributing to building a modern nation, as was the case in other Northern and Central European countries (see Metslaid 2016: 65). Estonian ethnography was a discipline deeply rooted in "our land and people", according to Gustav Ränk. He stated that studying Estonian folk culture was not merely the privilege of Estonian ethnographers, but their ultimate duty. Ethnography was a veritable rahousteadus - science of the nation. (Ränk 1935)

\section{THE FIRST SOVIET DECADE (1944-1956): COLLECTIVE FARMS AND ETHNOGENESIS}

The position of ethnography in Estonia was rather sad after the Second World War. Nearly every pre-eminent ethnographer had fled to the West, while others had suffered Soviet repression. ${ }^{6}$ Estonian ethnography was subjected to Soviet ideology and made part of Soviet ethnography.

By the 1940s, Soviet ethnography had become a well-controlled and centralised system culminating, at the apex of the pyramid, in the Institute of Ethnography at the Academy of Sciences of the USSR in Moscow. In the Soviet Union, the branch of scholarship dealing with peoples and their cultures was called ethnography, ${ }^{7}$ and it was treated as a sub-discipline of history. Its theoretical foundation was historical materialism. The basis was the evolutionist ideas of Lewis Henry Morgan and Friedrich Engels, which held that the development of human society is driven by progress occurring in the production of material benefits. Apart from this theoretical aspect, Soviet ethnography also had a practical side in that it had to contribute to the restructuring of society along socialist lines. 
Estonia had a major shortage of specialists in ethnography, but the ethnography professorship was not reinstated at the post-war sovietised University of Tartu. Initially archaeology professor Harri Moora (1900-1968) took responsibility for training new ethnographers. It fitted rather well with the Soviet logic as both archaeology and ethnography dealt mainly with the past through material culture and were considered offshoots of the study of history. Starting in 1950, the education of ethnographers continued in the department of history (Leete et al. 2008: 22).

One of the first steps in leading Estonian ethnography into the standard Soviet ideological model was the publication of an article entitled "Ethnography and the Present Day", by Sergei Tolstov, the director of the Institute of Ethnography in Moscow, in the ENM yearbook of 1947. It was translated from Sovetskaya etnografiya, the leading journal of Soviet ethnography, and was meant as an official statement from the Soviet Union's 'head ethnographer' (see Tolstov 1946).

Moora (1947) also published an article that adapted the demands of Soviet ethnography to Estonian conditions. He wrote that ethnography should continue to focus on the study of the old, pre-capitalist, peasant culture, but also lend more consideration to the socio-economic context of artefacts and phenomena (differentiation among peasantry, class struggle) and to the affect of the natural environment on traditional culture, as well as devoting more attention to neighbouring peoples (especially Russians). He also stressed the need to cooperate with neighbouring disciplines. His theses remained influential in Estonian ethnography for decades.

Moora was a nationally-minded scholar who was accused of 'bourgeois nationalism' and lost his professorship at University of Tartu in 1950. A man with diplomatic skill, he managed to escape the worse thanks to his good contacts with leading Soviet ethnographers from Moscow. (Leete et al. 2008: 23-24) Moora probably wanted to save ethnography as an Estonia-related discipline in Soviet circumstances and harshly criticised the research tradition founded by Manninen in his article (without mentioning him). Pre-war Estonian ethnography was not without its weaknesses of course, but it was also necessary to draw a sharp line between pre-war and Soviet Estonian ethnography. In fact, Moora maintained Manninen's legacy in many ways. ${ }^{8}$

After the war, the $\mathrm{ENM}^{9}$ was practically the only research institute in the Estonian SSR that dealt with ethnography. The ENM staff grew, but the museum's activity came under ideological control. In 1952, Moora established a small working group of ethnographers at the Soviet Estonian Academy of Sciences, Institute of History, sector of archaeology in Tallinn. This group became a kind of centre of excellence of Soviet Estonian ethnography, although it was separated from the rich ethnographic collections in Tartu. Viires (1918-2015), a student of Ränk, was the leader of the team there for decades.

In early 1949, one of the most authoritative Soviet ethnographers, Nikolai Cheboksarov, visited the Baltic republics. March 1950 saw a conference in Moscow organised by the Institute of Ethnography, which examined Baltic ethnography, with Estonian scholars participating. It was concluded that study should be directed above all to the socialist reform of worker and peasant daily life as at the ethnogenesis (it is origin and formation) of the Baltic peoples. (Leete et al. 2008: 23; Astel 2009: 224)

Soviet ethnography became interested in contemporary workers and peasants only in the late 1940s. Tolstov's and Moora's articles, mentioned above, were written before 
that turn, probably because of the need to demonstrate the significance of the discipline for Soviet society in the context of building communism (see FM: Luts 2004). ${ }^{10}$ Studies in ethnogenesis, on the other hand, began in the late 1930s. Peoples (in the ethnic sense) were the most important subjects of history, according to Joseph Stalin. Hence, the history of the Soviet Union meant the sum of histories of the Soviet peoples, starting with their origins and formation. (Abashin 2014: 152-153)

A series of training trips to museums and academic institutions in Leningrad was organised for Estonian ethnographers in the late 1940s so that they could become acquainted with 'advanced Soviet practices'. Leading Russian ethnographers (Cheboksarov, Vera Belitser, Natalya Schlygina, Rudolf Its) took part in teaching the discipline at the University of Tartu. (Piiri 1990: 175; Viires 1993: 15-16)

From 1952-1960, an integrated Baltic expedition operated, directed by the Institute of Ethnography in Moscow, but also involving young ethnographers (and specialists of neighbouring disciplines) from Baltic republics as apprentices. Moora acted as leader of the Estonian team. Contemporary socialist change and ethnogenesis were the main research topics.

The study of collective farms (kolkhozes), founded just recently in the atmosphere of fear created by the mass deportation of peasants, largely failed. Questionnaires composed by Soviet ethnographers did not work in the Estonian countryside: Estonian ethnographers were studying collective farms unwillingly, and the peasants were not eager to talk about the unpleasant present. (FM: Jaagosild 2004; FM: Võti 2004)

Research on ethnogenesis, on the other hand, was quite successful. It was an interdisciplinary project involving archaeologists, physical anthropologists, linguists, folklorists and ethnographers. The role of the latter was to study the material side of traditional folk culture, above all peasant architecture, folk costume, and agricultural tools in detail. They had to help to clarify the ethnic history of peoples and cultural ties between neighbours. In connection with this, the territorial structure of folk culture had also to be determined. It fitted well with the traditions of the discipline in Estonia. The work done in the 1920s and 1930s now proved a major asset. Even the historical-geographical method could continue in the new conditions. It merely needed to be salted with quotations from classic Marxist-Leninist works, and accents placed on the positive role of the Russian people. (Viires 1970a: 244; Leete et al. 2008: 23)

One of the outstanding accomplishments of research into the field of Estonian ethnogenesis was a collection of articles edited by Moora (1956a), Eesti rahva etnilisest ajaloost (Ethnic History of the Estonian People). The work envisioned Estonian roots as going back very far into the past, emphasised nativeness and thus supported identity. The claim that the forefathers of the Estonian people settled 5,000 years ago (Pit-Comb Ware culture) began here and was made popular some time later. The book was translated into Russian immediately (Moora 1956b) and was widely acknowledged in the Soviet Union and elsewhere (Viires 1993: 17).

\section{POSITIVE CHANGES IN SOVIET ESTONIAN ETHNOGRAPHY}

In the late 1950s, during the Khrushchev era 'thaw', a series of positive changes took place in Estonian ethnography. In March 1957 a meeting of ethnographers working 
under the umbrella of the Estonian Academy of Sciences was held in Tartu. ${ }^{11}$ This was followed by a decision from the Academy regarding the development of acquisitions at the ENM, stating that Ethnographic material in danger of irredeemable loss had to be collected, both in Estonia and in neighbouring territories. The effect of these decisions spanned decades. (Konksi 2009: 251)

Major changes took place in rural life during the post-war period, primarily in relation to the collectivisation of agriculture and rapid urbanisation. The last remnants of traditional Estonian folk culture were fading away and ethnographers considered it their duty to rescue what could still be saved. The tradition of salvage ethnography had survived the war and the first Soviet decade.

In April 1959, the 50th anniversary of the ENM was celebrated in grand fashion in Tartu. Essentially, this meant recognition of the tradition. The museum's yearbook was published for the first time in years, and a prestigious scientific conference was held. The anniversary spurred a rise in the ENM's reputation as a genuine research institution (Luts 1999: 37). Research conferences became an annual tradition and the yearbook has been published regularly since that time. ${ }^{12}$

Ties were forged also anew with Finnish colleagues during these years. Tartu was visited by Finnish ethnologists Kustaa Vilkuna, Toivo Vuorela and Niilo Valonen. The visits established a footing for long-term research contacts and friendships. (Luts 1999: 13-14, 34; Konksi 2009: 270) Contacts with 'bourgeois' Finland ${ }^{13}$ were very important for Estonian ethnographers, who had been totally isolated from the outside world in the post-war years. The new ties helped to spread ideas (for example, urban ethnology) and bolster self-confidence.

Soviet Estonian ethnography remained quite traditional, especially in terms of its topics, but also of its research methods. On one hand, this was promoted by the major cooperation projects launched by Moscow ethnographers, and on the other hand, by the choices made by Estonian ethnographers themselves.

\section{THE ATLAS PROJECT}

The first cooperation project was a study of ethnogenesis, mentioned above, and lasting until the 1960s. It directed Estonian ethnographers' interests to the past and fitted rather well with local disciplinary traditions. In the mid-1960s the compilation of the historical ethnographic atlas of the Baltic republics (Istoriko-etnograficheskiy atlas Pribaltiki) started, another task coordinated by the Institute of Ethnography in Moscow. The project grew out of the integrated Baltic expedition and ethnogenesis studies. In 1955 Soviet ethnographers Maksim Levin and Cheboksarov (1955: 13) published the theory of economic-cultural types and historical-ethnographical (or -cultural) areas, giving the Soviet Baltic republics as one example of the latter. This promoted cooperation between Baltic and Moscow ethnographers, which was not an easy task because traditions of ethnographic mapping were different (and almost lacking in Lithuania). (Atlas 1985: 8; Viires 1993: 21)

The Atlas Project meant traditional study of old artefacts and charting range maps, and as such took up a large part of Estonian ethnographers' energy until the late 1970s. The coordinators of the Estonian team were Viires and Aleksei Peterson (1931-2017), 
the director of the ENM and disciple of Moora and Viires. Two volumes, Zemledeliye (Agriculture, 1985) and Odezhda (Costumes, 1986), were published as the outcome of the work. Publication of the third volume, dedicated to settlements and buildings, failed because of disagreements between Latvian ethnographers and their colleagues from Moscow (Leete et al. 2008: 26), although the preparatory work had already been done.

Atlas looked into the past. Some maps went back to the mid-19th century, although most reflected realities of the late 19th and early 20th centuries - the favourite period of many Soviet and Estonian ethnographers. ${ }^{14}$ Only a couple of thematic maps out of the 54 in the Agriculture volume and 66 in the Costumes volume were based on materials from the 1930s and 1950s (Atlas 1985: 138; Atlas 1986: 173).

\section{THREE FAVOURITE RESEARCH TOPICS}

So, folk costume, peasant architecture and traditional agriculture remained the main research topics of Estonian ethnographers and were studied from a historical perspective, as a rule (see for example Viires 1993: 18, 24). Why? Let us have a closer look at each of these subject areas.

Folk costume was important above all in connection with Estonian Song Celebration traditions. The ethnographers at the ENM deemed it important for folk costume to be worn at festivals with as much historical verisimilitude as possible (Astel 2009: 238). Estonian folk costumes housed at the ENM (and nowhere else in such quantity) were originals, a yardstick of authenticity that could be used to fashion replicas worn in the modern era. Folk costume exhibitions, and publications, on the subject, both academic and non-academic, were always in demand. The making and wearing of folk costume gave people a way of identifying with their ethnic (and regional) roots and expressing national identity.

Estonian national costume has more than 100 regional variants - one for each church parish. Their academic research went hand in hand with serving the popular needs of folklorism, and some development did occur in methodology from the 1960s, especially in areas connected with folk art (see for example Üprus 1969; Kuigo 1969; Kirme 1982; Vunder 1992).

Official Soviet cultural policy promoted the use of folk costume. It was customary to highlight the ethnographic character of the Soviet people during holidays to demonstrate how national cultures were flourishing. Back in the 1925, Stalin wrote that Soviet culture had to be "national in form, socialist in content". ${ }^{15}$ Folk costumes (and folk art) fitted well into the role of 'national form'. The Soviet regime did not deny nationalities; it tolerated and even supported their existence. Only anti-Soviet (bourgeois) nationalism was condemned and persecuted. (See Slezkine 1994; Smith 2013: 218-229)

Thus, there was social demand for research into folk costume from both the authorities and at the grass-roots level, and it flourished throughout the Soviet period. ${ }^{16}$

As to peasant architecture, the principal feature of interest was the threshing room dwelling (rehielamu), which was widespread mainly in Estonia and extended into northern Latvia. This unique type of dwelling became a sort of national symbol and became important in the context of folklorism. As the kolkhoz system gained in strength and major drainage projects transformed the Estonian cultural landscape quickly in the 
1960s, threshing room dwellings began to disappear. The demolition of the structures in the course of these socialist changes was not mere replacement of one type of home with another, but a painful blow dealt to the nation's heritage. ${ }^{17}$

The first building at the open air museum founded in Tallinn in 1957 was a classic Sassi-Jaani threshing room dwelling from western Estonia. When it burnt down in 1984 for some obscure reason, a rumour spread among Estonians that it was set on fire by forces hostile to Estonian culture. (Viires 1993: 14) (The building was reconstructed and reopened in 1993.)

Threshing room dwellings and other old peasant houses became popular as summer homes in the last decades of the Soviet Union (see Annus 2019). Many of the Estonians who were born in the countryside and who then moved to towns in the course of rapid post-war urbanisation had a kind of idealised nostalgic view of their country childhoods and preferred to spend their holydays in former farm buildings, often decorated with traditional ethnographic objects (including disused agricultural tools).

Agriculture was the main livelihood of traditional Estonian peasants and rye bread (black bread) was considered their most important food, also a kind of national symbol. Hence, traditional agriculture, especially arable farming, was important topic from the standpoint of national identity. But agriculture and agricultural tools were also crucial for Soviet historical materialism because they stressed progress in the production of material benefits as the main force behind the development of human society. So, again, studying old agricultural methods and tools fitted well for both Estonian ethnographers and their academic supervisors in Moscow. ${ }^{18}$

Other facets of traditional folk culture were also dealt with during this period, of course, especially handicraft, transport, food, fishing and folk art.

Some Estonian ethnographers, first of all Peterson, director of the ENM between 1958 and 1992, devoted quite a lot of time and energy studying other Finno-Ugric peoples (see Auasi 2008). This too was connected with Estonian national identity, which is based mainly on language. Hence, linguistic relatives were (and are) important to many Estonians. (Jääts and Metslaid 2018: 122, 130; Jääts 2018: 47-51) Estonian ethnographers were looking into the past there too, and were not much interested in Soviet contemporaneity. First, in the late 1960s, their studies were connected with research into ethnogenesis, later the emphasis fell more on complementing ethnographic collections.

The intangible side of folk culture was studied by folkloristics, which was tied to linguistics and literature in the Soviet system. Folklorists also dealt with topics on the borderline between ethnography and folkloristics such as wedding customs and the folk calendar, as a rule. Religious life was also within their remit, although Estonian scholars were reluctant to deal with it as they were obliged to make their results contribute to the atheist struggle (see Pershits and Cheboksarov 1967: 18). ${ }^{19}$

\section{STUDYING CONTEMPORANEITY}

Studying contemporary everyday life was complicated and even disgusting for Estonian ethnographers, as it highlighted the ideological pressure under which they worked (FM: Võti 2004; FM: Jaagosild 2004; FM: Luts 2004; FM: Pärdi 2004; 2019). Ethnographers too had to make their contribution to state policies. Abram Pershits and Cheboksarov (1967: 
5, 13), two prominent Soviet ethnographers, stated that studies in contemporary ethnic and social processes were closely linked with building communism in the Soviet Union.

Failure to study collective farms in the late 1940s and early 1950s was already mentioned above. Attempts were made again in the early 1960s and later, when Estonian ethnographers already had a little more autonomy, but the published results remained scant as a rule. (Konksi 2004: 14; 2009: 311-326; Leete et al. 2008: 27) Only the research project, led by Arved Luts in the early 1960s in Võru County, was properly concluded and its results published (for example, Luts 1966 and elsewhere; see Konksi 2004 for details).

However, there was a continual pressure to study contemporary everyday life. Many Estonian ethnographers found a solution to this by adding a short overview section to their publications on the past that brought their research topic up to date.

Costumes, buildings, food, etc., were observed from the historical perspective and articles and books were published that still dealt mainly with traditional peasant culture, but ended with a paragraph or chapter dedicated to the contemporary situation (FM: Luts 2004). This kind of approach was accepted in Soviet ethnography as it demonstrated the progress that was taking place under socialism. Estonian ethnographers preferred to limit themselves to traditional peasant culture, which was tied to and supported Estonian national identity, although they sometimes had to pay the price and praise Soviet achievements to play the system.

Yet a certain broadening of the traditional subject areas of ethnography and methodology did take place in the late Soviet period, perhaps partly following the example set by Finnish colleagues (Viires 1993: 24; FM: Peterson 2004). Study was devoted to the pre-Soviet townspeople (working class) as well as to changes that occurred in Estonian folk culture from the latter half of the 19th century in connection with modernisation, industrialisation and urbanisation.

\section{CONCLUSION}

Estonian ethnography was tied with Estonian nationalism from the very beginning. It was one of the sciences of the nation (rahvusteadus). In the 1920s Manninen, the founding father of Estonian ethnography as an academic discipline, defined it as a science that mainly investigated the material side of traditional peasant culture. This kind of ethnography fitted surprisingly well with the Soviet understanding of ethnography as a sub discipline of history. The freedom enjoyed by Estonian ethnographers to choose their research topics was limited during the Soviet period. On the one hand they needed to respond to orders from Moscow, while on the other they wished to react to local popular demands, continue traditions of pre-war national science and support Estonian national identity. In general they managed to serve two masters, mainly because to a great extent the topics overlapped.

Thanks to major cooperative projects initiated and coordinated by ethnographers from Moscow (the integrated Baltic expedition, ethnogenesis studies, the historical ethnographical atlas of the Baltics) Estonian ethnographers were able to continue studying traditional peasant culture from the historical perspective. The favourite research topics of the Estonian ethnographers - folk costume, peasant architecture, and traditional 
agriculture - fitted the framework of the Soviet ethnography well, and were also important from the point of view of Estonian national identity.

However, studying contemporary (socialist) everyday life was unpopular among Estonian ethnographers because results had to support and justify Soviet policy. This they did unwillingly, avoiding doing so where possible, something that can be described as a kind of passive resistance. (See Viires 1991: 131; Vunder 1996: 15) It seems that in Estonia ethnography tended to draw people who valued national roots, tradition and identity, and were sceptical about Soviet-style progress.

Despite some interruption and repression during the Stalin era, ethnography survived as a science of the nation in Estonia. Estonian ethnographers were able to find their niche within Soviet ethnography. They focused on the Estonian people and Estonia, and to a lesser extent the Soviet Finno-Ugric peoples, preferring to research traditional peasant culture. They did not participate in the study of such important issues of Soviet ethnography as the history of ancient societies (forms of marriage, kinship systems) or contemporary ethnic processes.

During the Stalin era, it was assumed that culture would gradually become socialist in form, but in the closing decades of the Soviet era it also became national in content. The history of ethnography in Soviet Estonia was part of this process. Starting in the 1960s, led by a contingent of younger urban intellectuals, Estonians took new interest in their roots and started to value antiquity. Old folk culture was rediscovered and reconceptualised. A folkloristic movement quite independent of the regime developed out of this (see Kuutma 2008: 590). It can be said that since the late 1960s, ethnography and folklore were both somewhat in fashion. They were instruments for expressing one's national identity, and ethnographers did their part in supporting this trend through academic and popular publications and exhibitions. Ethnography as an Estonia-related discipline that mainly studied material peasant culture survived until the 1990s in Estonia and only then merged with contemporary European ethnology. One may say that Soviet rule in all its peculiarities had a preserving effect on Estonian ethnography.

\section{NOTES}

1 The discipline, mainly studying the material side of traditional peasant culture, was called 'ethnography' in Estonia up to the 1990s. Its counterpart in Russia and the Soviet Union, with a somewhat broader focus, was also labelled 'ethnography'. I use the term of the era under discussion in my article instead of 'ethnology'.

2 Viires acknowledges this himself (1993: 33).

3 No doubt this early ethnography and its possible effect on later Estonian ethnography deserves further investigation, but remains outside of scope of the present article. Estonian ethnographers' disciplinary identity has not included Baltic German and Russian scholars of the 19th century as a rule and little attention has been paid to their work. Ilmari Manninen (1924: 527), the founding father of Estonian ethnography, has stressed that ethnography was actually a new science in Estonia.

4 In addition to overviews of Estonian material folk culture a couple of important monographs were published during this period: A History of Estonian Folk Costume by Manninen (1927); Fishing on Lake Peipus (1934) and Farm Buildings of Saaremaa by Gustav Ränk (1939); and Older Estonian Apiculture I: Forest Apiculture by Ferdinand Linnus (1939). Both Ränk and Linnus had 
been Manninen's students. Ränk became the first professor of ethnography at the University of Tartu in 1939. Linnus served as ENM's director in 1928-1941.

5 In this connection, Helmi Kurrik (1883-1960), another Manninen's student, wrote a manual entitled Eesti rahvarõivad (Estonian Folk Costume, 1938). (For more on this, see Nõmmela 2010.)

6 ENM director Ferdinand Linnus was arrested in summer 1941 and died in prison camp in Russia the following year. Several of the most competent staff at the ENM, including director Ida Kaldmaa, were fired in 1950 as part of the campaign against 'bourgeois nationalists'.

7 The discipline had this name already in Tsarist Russia. The tradition continued in the Soviet Union and helped preserve the label in Estonia as well.

8 Harri Moora's wife Aliise Moora, a well-established Soviet Estonian ethnographer, was one of Manninen's students; Harri Moora also attended Manninen's lectures on ethnography in the 1920s (Viires 1970b: 23).

9 The name of the museum changed repeatedly during the Soviet era. In the interest of simplicity, we use the designation Estonian National Museum (ENM) throughout the article.

10 Moora reacted quite quickly, orginised a meeting of museum staff and students in June 1949, and explained how to study kolkhozes from a historical perspective (Viires 1970b: 26).

11 The ENM was put under the Estonian Academy of Sciences between 1946 and 1963; thereafter, it was subjected to the Ministry of Culture of the Estonian SSR. This meant lower salaries (as compared to the Academy) and a focus on complementing the collections rather than research. However, thanks to Aleksei Peterson, Jüri Linnus and others, the museum managed to survive as an important academic institution.

12 The ENM's yearbook was started in 1925. The first volume after the war was published in 1947 and was numbered I (XV) - a kind of compromise between stressing the new start and maintaining continuity. Then, after another pause, volume XVI was issued in 1959. Hence, continuity won.

13 Finland had lost the war against the Soviet Union, but stayed 'bourgeois' as it was allowed to keep a capitalist economy, extensive academic freedom and contact with the West. On the other hand, it was a 'friendly' country controlled by the Soviet Union, resulting in Finns being allowed to visit Estonia.

14 It was safe to deal with this period as it was politically unloaded yet relatively well covered by traditional ethnographic sources.

15 Stalin presented the concept of culture socialist (proletarian) in content and national in form in his speech delivered at a meeting of students of the Communist University of the Toilers of the East on May 18, 1925. It was first published in Pravda, and became very influential. (Stalin 1925; see also Connor 1984: 202, 240-241)

16 The most important publications on the topic were Estonian Folk Costume from the 19th and Early 20th Centuries, edited by Moora (1957) and Estonian Folk Costume by Melanie Kaarma and Aino Voolmaa (1981).

17 The outstanding publications covering peasant architecture were Estonian Peasant Architecture by Karl Tihase (1974) and Folk Architecture by Tamara Habicht (1977).

18 The most important publications on agriculture were Estonian Agriculture from the 18th to the Early 20th Century by Liviya Feoktistova (1980), and articles by Endla Jaagosild (see for example 1972), Ildike Jaagosild (1969) and Ellen Karu (1971).

19 The Estonian version of this article, first published in Sovetskaya etnografiya, the leading journal of Soviet ethnography, was published in 1968. 


\section{SOURCES}

FM: Jaagosild 2004 = Endla Jaagosild, interview with Karin Konksi, 22/09/2004.

FM: Luts 2004 = Arved Luts, interviews with Karin Konksi, 28/01 and 15/09/2004.

FM: Peterson 2004 = Aleksei Peterson, interview with Karin Konksi, 25/05/2004.

FM: Võti 2004 = Tiina Võti, interview with Karin Konksi, 26/01/2004.

FM: Pärdi 2004 = Heiki Pärdi, interview with Karin Konksi, 2004.

FM: Pärdi 2019 = Heiki Pärdi, interview with Indrek Jääts, 26/02/2019.

\section{REFERENCES}

Abashin, Sergey. 2014. Ethnogenesis and Historiography: Historical Narratives for Central Asia in the 1940s and 1950s. - An Empire of Others: Creating Ethnographic Knowledge in Imperial Russia and the USSR, edited by Roland Cvetkovski and Alexis Hofmeister. Budapest; New York: CEU Press, 145-169.

Annist, Aet and Maarja Kaaristo. 2013. Studying Home Fields: Encounters of Ethnology and Anthropology in Estonia. - Journal of Baltic Studies 44 (2): 121-151. DOI: https://doi.org/10.108 0/01629778.2013.775846.

Annus, Epp. 2019. Maakodu Eesti NSV-s: kultuurilised kujutelmad ja argised asjad. - Keel ja Kirjandus 6: 425-440.

Astel, Eevi. 2009. Eesti Rahva Muuseum aastatel 1940-1957. - Eesti Rahva Muuseumi 100 aastat, compiled by Piret Õunapuu. Tartu: Eesti Rahva Muuseum, 186-247.

Atlas 1985 = Istoriko-etnograficheskiy atlas Pribaltiki: Zemledeliye. Vil'nyus: Mokslas. [Историкоэтнографический атлас Прибалтики: Земледелие. Вильнюс: Мокслас.]

Atlas 1986 = Istoriko-etnograficheskiy atlas Pribaltiki: Odezhda. Riga: Zinatne. [Историкоэтнографический атлас Прибалтики: Одежда. Рига: Зинатне.]

Auasi 2008 = Auasi: Eesti etnoloogide jälgedes. A Matter of Honour: In the Footsteps of Estonian Ethnologists. Дело чести: по следам эстонских этнологов, compiled by Svetlana Karm, Marleen Nõmmela and Piret Koosa. Tartu: Eesti Rahva Muuseum.

Connor, Walker. 1984. The National Question in Marxist-Leninist Theory and Strategy. Princeton, NJ: Princeton University Press.

Feoktistova, Liviya. 1980. Zemledeliye u estontsev XVIII - nachalo XX v.: Sistemy i tekhnika. Moskva: Nauka. [Феоктистова, Аивия. 1980. Земледелие у эстонцев: XVIII - начало XX в.: Системь и техника. Москва: Наука.]

Habicht, Tamara. 1977. Rahvapärane arhitektuur. Eesti rahvakunst 2. Tallinn: Kunst.

Hroch, Miroslav. 2000. Social Preconditions of National Revival in Europe: A Comparative Analysis of the Social Composition of Patriotic Groups among the Smaller European Nations. New York, NY: Columbia University Press.

Jaagosild, Endla. 1972. Rukki kuivatamine põllul. - Etnograafiamuuseumi aastaraamat XXVI. Tallinn: Valgus, 95-118.

Jaagosild, Ildike. 1969. Laudad Lääne-Eestis ja saartel. - Etnograafiamuuseumi aastaraamat XXIV. Tallinn: Valgus: 163-194.

Johansen, Ulla. 1996. Die Ethnologen und die Ideologien: Das Beispiel der estnischen Ethnographen in der Sowjetzeit. - Zeitschrift für Ethnologie 121 (2): 181-202.

Jääts, Indrek. 2018. Eesti etnograafid lõunavepsa külades 1965-1969. - Eesti Rahva Muuseumi aastaraamat 61. Tartu: Eesti Rahva Muuseum, 44-79. DOI: https://doi.org/10.33302/ermar-2018-002.

Jääts, Indrek and Marleen Metslaid. 2018. Eesti etnograafia ja eesti rahvuslus. - Keel ja Kirjandus 1-2: 118-135. 
Kaarma, Melanie and Aino Voolmaa. 1981. Eesti rahvarõivad. Tallinn: Eesti Raamat.

Karu, Ellen. 1971. Suviviljapeks Eestis 19. sajandi teisel poolel ja 20. sajandi algul. - Etnograafiamuuseumi aastaraamat XXV. Tallinn: Valgus, 185-206.

Kirme, Kaalu. 1982. Eesti sõled. Tallinn: Kunst.

Konksi, Karin. 2004. Arved Luts ja Nõukogude Eesti kaasaja dokumenteerimine Eesti Rahva Muuseumis. - Eesti Rahva Muuseumi aastaraamat XLVIII. Tartu: Eesti Rahva Muuseum, 13-46.

Konksi, Karin. 2009. Etnograafiamuuseumina Nõukogude Eestis 1957-1991. - Eesti Rahva Muuseumi 100 aastat, compiled by Piret Õunapuu. Tartu: Eesti Rahva Muuseum, 250-355.

Kuigo, Elle. 1969. Naistesärkide kaunistused Eestis XIX sajandil. - Etnograafiamuuseumi aastaraamat XXIV. Tallinn: Valgus, 75-125.

Kurrik, Helmi. 1938. Eesti rahvarõivad. Tartu: Eesti Rahva Muuseum.

Kuutma, Kristin. 2008. Rahvakultuurisajand omakultuurist folklooriliikumiseni. - Eesti rahvakultuur, edited by Ants Viires and Elle Vunder. Tallinn: Entsüklopeediakirjastus, 586-598.

Leete, Art; Ülo Tedre, Ülo Valk and Ants Viires. 2008. Uurimislugu. - Eesti rahvakultuur, edited by Ants Viires and Elle Vunder. Tallinn: Entsüklopeediakirjastus, 15-39.

Levin, Maksim and Nikolay Cheboksarov. 1955. Khozyaystvenno-kul'turnyye tipy i istoriko-etnograficheskiye oblasti. - Sovetskaya etnografiya 4: 3-17. [Левин, Максим; Николай Чебоксаров. 1955. Хозяйственно-культурные типы и историко-этнографические области. - Советская этнография 4: 3-17.]

Linnus, Ferdinand. 1939. Eesti vanem mesindus I: metsamesindus. Tartu: Eesti Rahva Muuseum.

Luts, Arved, ed. 1966. Etnograafiamuuseumi aastaraamat XXI. Tallinn: Valgus.

Luts, Arved. 1999. Teel juubelile: tagasivaade Eesti Rahva Muuseumi 50 aastapäevale ja selle eelloole. - Eesti Rahva Muuseumi aastaraamat XLIII. Tartu: Eesti Rahva Muuseum, 11-49.

Löfgren, Orvar. 1990. The Danger of Knowing What You Are Looking For: On Routinizing Research. - Ethnologia Scandinavica 20: 3-15.

Manninen, Ilmari. 1924. Etnograafia tegevuspiiridest ja sihtidest Eestis. - Eesti Kirjandus 12: 527537.

Manninen, Ilmari. 1927. Eesti rahvariiete ajalugu. Eesti Rahva Muuseumi aastaraamat III. Tartu: Eesti Rahva Muuseum.

Metslaid, Marleen. 2016. Between the Folk and Scholarship: Ethnological Practice in Estonia in the 1920s and 1930s. Dissertationes Ethnologiae Universtitatis Tartuensis 5. Tartu: University of Tartu Press.

Moora, Harri. 1947. Eesti etnograafia nõukogulikul ülesehitamisel. - Eesti Rahva Muuseumi aastaraamat I (XV). Tartu: Teaduslik Kirjandus, 24-35.

Moora, Harri. 1956a. Eesti rahva etnilisest ajaloost. Tallinn: Eesti Riiklik Kirjastus.

Moora, Harri. 1956b. Voprosy etnicheskoy istorii estonskogo naroda: Sbornik statey. Tallinn: Estonskoye gosudarstvennoye izdaltel'stvo. [Моора, Харри. 1956. Вопросы этнической истории эстонского народа: Сборник статей. Таллин: Эстонское государственное издательство.]

Moora, Harri, ed. 1957. Eesti rahvarõivaid XIX sajandist ja XX sajandi algult. Tallinn: Eesti Riiklik Kirjastus.

Niglas, Liivo and Eva Toulouze. 2010. Reconstructing the Past and the Present: The Ethnographic Films Made by the Estonian National Museum (1961-1989). - Journal of Ethnology and Folkloristics 4 (2): 77-96.

Nõmmela, Marleen. 2010. The State, the Museum and the Ethnographer in Constructing National Heritage: Defining Estonian National Costumes in the 1930s. - Journal of Ethnology and Folkloristics 4 (1): 49-61.

Pershits, Abram and Nikolay Cheboksarov. 1967. Polveka sovetskoy etnografii. - Sovetskaya etnografiya 5: 3-24. [Першиц, Абрам; Николай Чебоксаров. 1967. Полвека советской этнографии. - Советская этнография 5: 3-24.]

Pershits and Cheboksarov 1968 = Peršits, Abram and Nikolai Tšeboksarov. 1968. Pool sajandit nõukogude etnograafiat. - Etnograafiamuuseumi aastaraamat XXIII. Tallinn: Valgus, 7-28. 
Peterson, Aleksei. 1966. Eesti Nõukogude etnograafia aastail 1940-1965. - Etnograafiamuuseumi aastaraamat XXI. Tallinn: Valgus, 9-31.

Piiri, Reet. 1990. Eesti Rahva Muuseumi sidemed teadusasutustega väljaspool Eestit 1909-1987. - Eesti Rahva Muuseumi aastaraamat XXXVIII. Tartu: Eesti Rahva Muuseum, 170-203.

Ränk, Gustav. 1934. Peipsi kalastusest. Tartu: Õpetatud Eesti Selts.

Ränk, Gustav. 1935. Päevaküsimusi eesti rahvusteaduste töömailt. - Üliõpilasleht 5, April 7: 178181.

Ränk, Gustav. 1939. Saaremaa taluehitised; etnograafiline uurimus 1. Ehitiste üksikosad, elamu ja kõrvalhooned, mis osalt täidavad elamu ülesandeid. Tartu: Õpetatud Eesti Selts.

Ränk, Gustav. 1978. Ethnographic Studies. - A Case Study of a Soviet Republic: The Estonian SSR, edited by Tönu Parming and Elmar Järvesoo. Boulder, CO: Westview Press, 319-339. DOI: https://doi.org/10.4324/9780429047695-10.

Slezkine, Yuri. 1994. The USSR as a Communal Apartment, or how a Socialist State Promoted Ethnic Particularism. - Slavic Review 53 (2): 414-452. DOI: https://doi.org/10.2307/2501300.

Smith, Jeremy. 2013. Red Nations: The Nationalities Experience in and after the USSR. New York, NY: Cambridge University Press. DOI: https://doi.org/10.1017/CBO9781139047746.

Stalin, Joseph. 1925. The Political Tasks of the University of the Peoples of the East. Speech delivered at a Meeting of Students of the Communist University of the Toilers of the East. - Pravda 115, May 22, 1925. https://www.marxists.org/reference/archive/stalin/works/1925/05/18.htm (accessed October 24, 2019).

Talve, Ilmar. 1992. Ilmari Manninen in Finland and Estonia. - Pioneers: The History of Finnish Ethnology. Studia Fennica Ethnologica I, edited by Matti Räsänen. Helsinki: Suomalaisen Kirjallisuuden Seura, 50-76.

Tihase, Karl. 1974. Eesti talurahvaarhitektuur. Tallinn: Kunst.

Tolstov, Sergey. 1946. Etnografiya i sovremennost'. - Sovetskaya etnografiya 1: 3-11. [Толстов, Сергей. 1946. Этнография и современность. - Советская этнография 1: 3-11.]

Tolstov, Sergei. 1947. Etnograafia ja nüüdisaeg. - Eesti Rahva Muuseumi aastaraamat I (XV). Tartu: Teaduslik Kirjandus, 11-23.

Üprus, Helmi. 1969. Eesti rahvakunst kunstiajaloo aspektist. - Etnograafiamuuseumi aastaraamat XXIV. Tallinn: Valgus, 7-40.

Viires, Ants. 1970a. Etnograafilise mõtte arengu põhijooni. - Leninlik etapp eesti ajalooteaduses: historiograafilisi artikleid, edited by Endel Laul. Tallinn: Eesti Raamat, 231-251.

Viires, Ants. 1970b. Harri Moora ja eesti etnograafia. - Studia Archaeologica in Memoriam Harri Moora, edited by Marta Schiedehelm, Lembit Jaanits and Jüri Selirand. Tallinn: Valgus, 23-27.

Viires, Ants. 1991. The Development of Estonian Ethnography during the 20th Century. - Journal of Baltic Studies 22 (2): 123-132. DOI: https://doi.org/10.1080/01629779100000021.

Viires, Ants. 1993. Etnograafia arengust Eesti NSV päevil (1940-1990). - Muunduv rahvakultuur: etnograafilisi uurimusi, edited by Ants Viires. Tallinn: Eesti Teaduste Akadeemia, 5-37.

Viires, Ants and Ülo Tedre. 1998. Uurimislugu. - Eesti rahvakultuur, compiled and edited by Ants Viires and Elle Vunder. Tallinn: Eesti Entsüklopeediakirjastus, 15-45.

Vunder, Elle. 1992. Eesti rahvapärane taimornament tikandis. Tallinn: Kunst.

Vunder, Elle. 1996. Ethnology at the University of Tartu in Historical Perspective. - How to Make Ethnologists. Pro Ethnologia 4, edited by Heiki Pärdi, Toivo Sikka and Ivi Tammaru. Tartu: Estonian National Museum, 7-30. 